\title{
Perancangan Sistem Disinfektan UV-C Sterilisasi Paket sebagai Pencegahan Penyebaran Covid-19
}

\author{
(Design of Package Sterilization UV-C Disinfectant Systems \\ to Prevent the Spread of Covid-19)
}

\author{
Reza Satria Rinaldi ${ }^{1}$, Ika Novia Anggraini ${ }^{2}$
}

\begin{abstract}
This research is based on the societies' needs to sterilize the goods from delivery services during the Covid-19 pandemic. Due to the societies' needs, the delivery and logistics services did the sterilization of the goods by spraying disinfectant liquid in and out packages that gave impact to the wetness of packages. Therefore, innovation was needed to carry out the sterilization of goods and logistics so that they can be received or sent in good condition. The ultraviolet $\mathrm{C}$ (UV-C) disinfectant was this innovation. In this study, the design of a UV-C disinfectant system for sterilizing packages through a mini conveyor has been made. Then, a UV-C disinfectant system with a sterilization area of $90 \mathrm{~cm}$ long, $50 \mathrm{~cm}$ wide, and $50 \mathrm{~cm}$ high is used. The system needs a UV-C lamp with the power of 161.77 watts for the sterilization. The results of irradiation measurements of the UV-C disinfectant system is used to calculate the length of UV-C exposure time. Based on the calculation results, the designed UV. C disinfectant system was able to kill the virus up to $90 \%$ of the coronavirus within the length of UV-C exposure time toward the package in the sterilization area of at least 16 seconds.
\end{abstract}

Intisari-Makalah ini dilatarbelakangi oleh adanya kebutuhan masyarakat terhadap sterilisasi barang-barang yang diperoleh dari jasa pengiriman barang selama pandemi Covid-19. Dengan adanya kebutuhan masyarakat tersebut, jasa pengiriman dan logistik melakukan sterilisasi berupa penyemprotan cairan disinfektan pada paket yang keluar masuk sehingga berdampak pada basahnya paket. Oleh karena itu, perlu satu upaya baru untuk melakukan sterilisasi barang dan logistik agar barang dan logistik yang diterima atau dikirim tetap dalam kondisi baik. Disinfektan ultraviolet C (UV-C) merupakan upaya baru tersebut. Dalam makalah ini, telah dibuat rancangan sebuah sistem disinfektan UV-C untuk sterilisasi paket melalui konveyor mini. Selanjutnya, dibuat area sterilisasi sistem disinfektan UV-C berukuran panjang $90 \mathrm{~cm}$, lebar $50 \mathrm{~cm}$, dan tinggi $50 \mathrm{~cm}$. Sistem disinfektan UV-C yang dirancang membutuhkan daya lampu UVC sebesar 161,77 watt untuk sterilisasi pada sistem disinfektan UV-C. Hasil pengukuran iradiasi sistem disinfektan UV-C digunakan untuk menghitung lama waktu paparan UV-C. Berdasarkan hasil perhitungan, sistem disinfektan UV-C yang dirancang mampu membunuh hingga $90 \%$ virus corona dengan lama waktu paparan UV-C terhadap paket dalam area sterilisasi minimal 16 detik.

Kata Kunci-Disinfektan UV-C, Sterilisasi, Paket, Covid-19.

1,2 Program Studi Teknik Elektro Fakultas Teknik Universitas Bengkulu, Jl. W.R. Supratman Kelurahan Kandang Limun Kecamatan Muara Bangkahulu Kota Bengkulu 38371 INDONESIA (tlp: 0736-21170, 21884; fax: 0736-22150, 20815; e-mail: reza_s_r@unib.ac.id,ikanovia@unib.ac.id )

\section{Pendahuluan}

Wabah Coronavirus Disease 2019 (Covid-19), yang ditemukan pada Desember 2019 di Wuhan, Provinsi Hubei, Republik Rakyat China, telah menyebar ke banyak negara di dunia. Oleh karena itu, pada 30 Januari 2020 Komite Darurat World Health Organization (WHO) menyatakan keadaan darurat kesehatan global [1]. Pasien pertama positif Covid-19 di Indonesia diumumkan oleh Presiden Joko Widodo pada 2 Maret 2020 [2]. Kasus positif Covid-19 di Indonesia setiap hari mengalami peningkatan.

Gugus tugas penanganan Covid-19 menyatakan kurang lebih 90\% kasus penularan Covid-19 terjadi melalui droplet atau tetesan yang masuk ke mata, hidung, dan mulut yang dibawa oleh jari. First line defense atau pertahanan paling depan adalah menggunakan masker dan cuci tangan. Second line defense atau pertahanan berikutnya adalah perilaku menjaga kebersihan dengan mandi setelah bepergian, mencuci baju, dan membersihkan permukaan barang dengan disinfektan [3].

Walaupun belum ditemukan penularan Covid-19 secara langsung lewat barang, tetapi upaya pencegahan juga dilakukan oleh jasa pengiriman barang dan logistik serta jasa penjualan daring (online). Sebagai upaya mencegah dan meminimalkan penyebaran Covid-19, sejumlah jasa pengiriman barang dan logistik melakukan kebijakan seperti sterilisasi berupa penyemprotan cairan disinfektan pada paket yang keluar masuk dan mengimbau pelanggannya untuk membersihkan atau mencuci isi paket sebelum digunakan [4]-[5].

Columbia University Medical Center melaporkan untuk pertama kalinya bahwa sinar Far-UVC dengan dosis sangat rendah membunuh lebih dari $95 \%$ virus influenza $\mathrm{H} 1 \mathrm{~N} 1 \mathrm{di}$ udara. Far-UVC merupakan sinar ultraviolet C (UV-C) yang memancarkan spektrum sempit UV-C pada panjang gelombang sekitar 222 nanometer [6]. FTUI mengembangkan Bilik Disinfeksi Cepat (BDC)-04 dengan menggunakan sinar Far-UVC. Penggunaan bilik ini akan menjaga baju tetap kering karena menggunakan sinar UV, tidak seperti kebanyakan bilik serupa yang telah beredar. Dengan pemaparan (fluence) sinar UV selama 5-10 detik, efektivitas dalam menonaktifkan mikroorganisme yang menempel pada pakaian atau tubuh manusia mencapai 89-99 persen [7].

Pada sterilisasi menggunakan UV-C, iradiasi intensitastinggi waktu-singkat dengan iradiasi intensitas-rendah waktulama memiliki dosis dan efek sterilisasi yang sama. Hasil iradiasi terbaik adalah pada jarak antara 1,25-1,5 cm dan waktu sekitar 10-12 detik [8]. Dengan demikian, semakin lama waktu 
iradiasi atau semakin besar intensitas iradiasi UV-C akan memberikan hasil sterilisasi yang baik.

Sinar UV-C belum dimanfaatkan untuk sterilisasi paket pada jasa pengiriman barang. Sejak terjadinya pandemi Covid-19, sterilisasi paket pada jasa pengiriman barang dilakukan secara manual dengan penyemprotan disinfektan cair pada setiap paket yang keluar masuk. Hal ini tentunya cukup merepotkan dan kurang efektif. Penyemprotan disinfektan juga dapat mengakibatkan paket basah, terutama jika disinfektan disemprotkan secara berlebihan. Adanya proses sterilisasi terhadap setiap paket yang keluar masuk juga menambah waktu operasional, terlebih lagi pada saat arus keluar masuk paket yang besar.

Untuk mengurangi waktu operasional dalam proses sterilisasi setiap paket, dapat digunakan sebuah sistem konveyor mini yang dilengkapi dengan sistem disinfektan UV-C. Penggunaan disinfektan UV-C merupakan sebuah pilihan yang cukup baik untuk mengatasi kelemahan penyemprotan disinfektan cair. Selama ini sinar UV-C baru dimanfaatkan untuk sterilisasi tanpa menggunakan konveyor [9]-[12]. Berdasarkan hal tersebut, dalam makalah ini dirancang sebuah sistem disinfektan UV-C otomatis untuk sterilisasi paket melalui konveyor mini. Dengan menggunakan sistem ini, diharapkan proses sterilisasi paket melalui konveyor mini akan menjadi lebih efektif.

\section{CovID-19}

Covid-19 merupakan nama penyakit yang disebabkan oleh virus yang diberi nama oleh WHO sebagai Severe Acute Respiratory Syndrome Coronavirus-2 (SARS-CoV-2). Pada 11 Maret 2020, Covid-19 dinyatakan oleh WHO sebagai wabah pandemi global. Kejadian luar biasa yang disebabkan oleh virus corona saat ini bukanlah merupakan kejadian yang pertama kali. Sebelumnya, pada tahun 2002, ada SARS yang disebabkan SARS-coronavirus (SARS-CoV) dengan 8000-an kasus. Kemudian, ada Middle East Respiratory Syndrome (MERS) pada tahun 2012, yang disebabkan oleh MERS-Coronavirus (MERS-CoV) dengan 1000-an kasus [13].

Virus corona diselimuti oleh virus RNA untai tunggal positif yang banyak menginfeksi manusia, tetapi juga menginfeksi berbagai hewan [1]. Struktur virus corona membentuk struktur seperti kelompok (club-like) dengan protein $\mathrm{S}$ berlokasi di permukaan virus. Pengenalan sifat fisik dan kimiawi dari virus corona terutama berasal dari studi SARS-CoV dan MERS$\mathrm{CoV}$. Virus corona bersifat sensitif terhadap panas dan secara efektif dapat dinonaktifkan oleh disinfektan yang mengandung klorin, pelarut lemak dengan suhu $56^{\circ} \mathrm{C}$ selama 30 menit, eter, alkohol $75 \%$, peroxyacetic acid, dan kloroform. Sementara itu, chlorhexidine tidak efektif dalam menonaktifkan virus [14].

\section{ULTRAVIOLET (UV) SEBAGAI DISINFEKTAN}

Ultraviolet adalah radiasi elektromagnetis yang tidak terlihat oleh manusia. Ultraviolet mempunyai beberapa penyebutan yang pada dasarnya sama, di antaranya cahaya ultraviolet, sinar ultraviolet, radiasi ultraviolet, radiasi elektromagnetis ultraviolet, atau secara sederhana disingkat UV. UV dapat dibagi menjadi beberapa kategori. Kategori yang paling umum adalah UV-A (320-390 nm), yang juga disebut longwave atau blacklight; UV-B (280-315 nm), yang juga disebut mid-wave; dan UV-C (200-280 nm), yang juga disebut shortwave dan germicidal light. Penamaan dan pengkategorian UV lainnya adalah Near UV (300-400 nm), Far UV (122-200 nm); Vacuum UV (10-200 nm); dan Extreme UV (10-121 nm) [15].

Pemaparan sinar UV selama 10 detik memberikan efektivitas sebesar $64,21 \%$ terhadap penurunan jumlah bakteri pada uang kertas yang beredar di masyarakat pada masa pandemi Covid-19 [9]. Hasil ini sejalan dengan penelitian sterilisasi peralatan makan menggunakan metode pemaparan sinar UV. Dalam penelitian tersebut, digunakan lampu UV 25 watt dengan jarak $10 \mathrm{~cm}$ dari objek. Berdasarkan hasil pengujian proses sterilisasi selama 1 menit, 5 menit, 10 menit, dan 15 menit, diperoleh hasil bahwa tingkat kesterilan alat makan mencapai $100 \%$ (bakteri tersisa 0 koloni $/ \mathrm{cm}^{2}$ dengan pertumbuhan 0\%) untuk proses sterilisasi selama 15 menit [10].

Sebuah alat sterilisasi udara didesain menggunakan sinar ultraviolet dengan panjang gelombang $(\lambda)$ 260-265 nm dan daya sebesar 8 watt. Alat ini memiliki kemampuan untuk mereduksi jumlah bakteri yang sangat signifikan, mencapai 92,7\% untuk mikroorganisme berjenis bakteri dan $94,1 \%$ fungi pada volume ruangan $1 \mathrm{~m}^{3}$ dengan waktu perlakuan (treatment) selama 45 menit [11]. Pada penelitian lainnya, alat disinfeksi ruangan berbasis radiasi UV-C yang terdiri atas empat lampu UV-C Phillips TUV-T8 30 watt yang ditempatkan pada empat sisi yang berbeda diuji. Hasil pengujian menunjukkan bahwa paparan UV-C selama 15 menit sudah cukup untuk menghilangkan inokulum [12].

\section{METODE}

Makalah ini merupakan sebuah penelitian terapan yang bertujuan untuk memecahkan masalah-masalah kehidupan praktis, dalam hal ini upaya pencegahan penyebaran Covid-19. Penelitian ini lebih bersifat praktis dan aplikatif. Dalam makalah ini dirancang sebuah teknologi tepat guna berupa sebuah sistem disinfektan UV-C. Penelitian difokuskan pada pengukuran tingkat distribusi iradiasi UV-C dalam area sterilisasi sistem disinfektan UV-C sehingga dapat dihitung lama paparan UV-C untuk membunuh virus corona. Dosis paparan UV-C $(D)$ merupakan fungsi perkalian lama waktu paparan UV-C $\left(E_{t}\right)$ terhadap tingkat iradiasi $\left(I_{R}\right)[16]$.

$$
D=E_{t} \cdot I_{R}
$$

Sistem konveyor mini yang dirancang memiliki panjang $110 \mathrm{~cm}$ dan lebar $50 \mathrm{~cm}$. Sistem ini digunakan untuk melewatkan paket dengan dimensi maksimal panjang $70 \mathrm{~cm}$, lebar $40 \mathrm{~cm}$, dan tinggi $40 \mathrm{~cm}$. Berdasarkan hal tersebut, sistem disinfektan UV-C dirancang dengan area sterilisasi berukuran panjang $90 \mathrm{~cm}$, lebar $50 \mathrm{~cm}$, dan tinggi $50 \mathrm{~cm}$. Ukuran (panjang) lampu UV-C yang digunakan menyesuaikan dengan ukuran area sterilisasi sistem disinfektan dan konveyor mini. Rancangan sistem ini diperlihatkan pada Gbr. 1, dengan cara kerja sistem seperti diagram alir pada Gbr. 2.

Semua sisi permukaan paket harus terkena paparan iradiasi UV-C tanpa harus mengubah posisi paket saat berada di atas konveyor mini. Belt pada konveyor mini yang digunakan untuk 


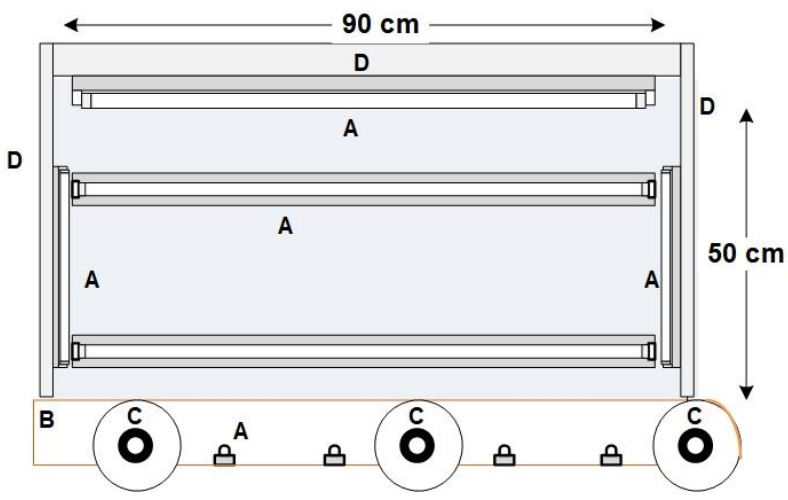

(a)

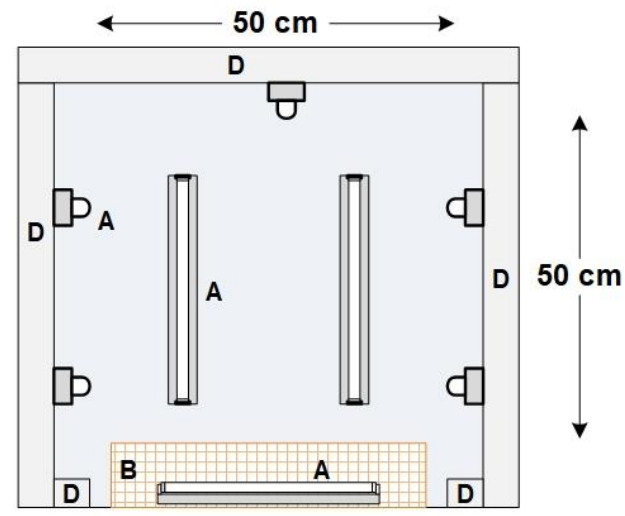

(b)

$$
\begin{array}{rll}
\text { Ket.: } & \mathrm{A}=\text { Lampu UV-C } & \mathrm{C}=\text { Roller } \\
& \mathrm{B}=\text { Conveyor } & \mathrm{D}=\text { Rangka Sistem }
\end{array}
$$

Gbr. 1 Potongan rancangan sistem, (a) tampak samping, (b) tampak depan/ belakang.

melewatkan paket harus dapat melewatkan iradiasi UV-C agar permukaan bawah paket terpapar iradiasi UV-C. Berdasarkan hal tersebut, belt pada konveyor mini yang merupakan sisi bawah area sterilisasi sistem disinfektan UV-C berupa jaring, yaitu wire mesh teflon.

Paket yang masuk dan dilewatkan melalui konveyor mini diukur dimensinya oleh sistem sensor pada konveyor mini yang terintegrasi dengan sistem disinfektan UV-C. Berdasarkan dimensi paket tersebut, dapat ditentukan lama waktu paparan UV-C yang dibutuhkan untuk proses sterilisasi paket. Kerja sistem disinfektan UV-C dimulai dengan masuknya paket yang dilewatkan konveyor mini ke dalam area sterilisasi. Saat paket telah berada di tengah area sterilisasi sistem disinfektan UV-C, konveyor akan berhenti, sisi depan dan belakang area sterilisasi menutup, dan proses sterilisasi dimulai, yaitu dengan menyalanya lampu-lampu UV-C dalam area sterilasi. Setelah lama waktu penyinaran iradiasi UV-C tercapai, lampu-lampu UV-C akan padam, sisi depan dan belakang area sterilisasi membuka, dan konveyor kembali bergerak untuk membawa paket keluar dari area sterilisasi.

Untuk memastikan sistem disinfektan UV-C sudah dapat berfungsi dengan baik, dilakukan pengujian hasil rancangan. Jika sistem belum berfungsi dengan baik, akan diadakan evaluasi dan pengecekan rancangan untuk selanjutnya

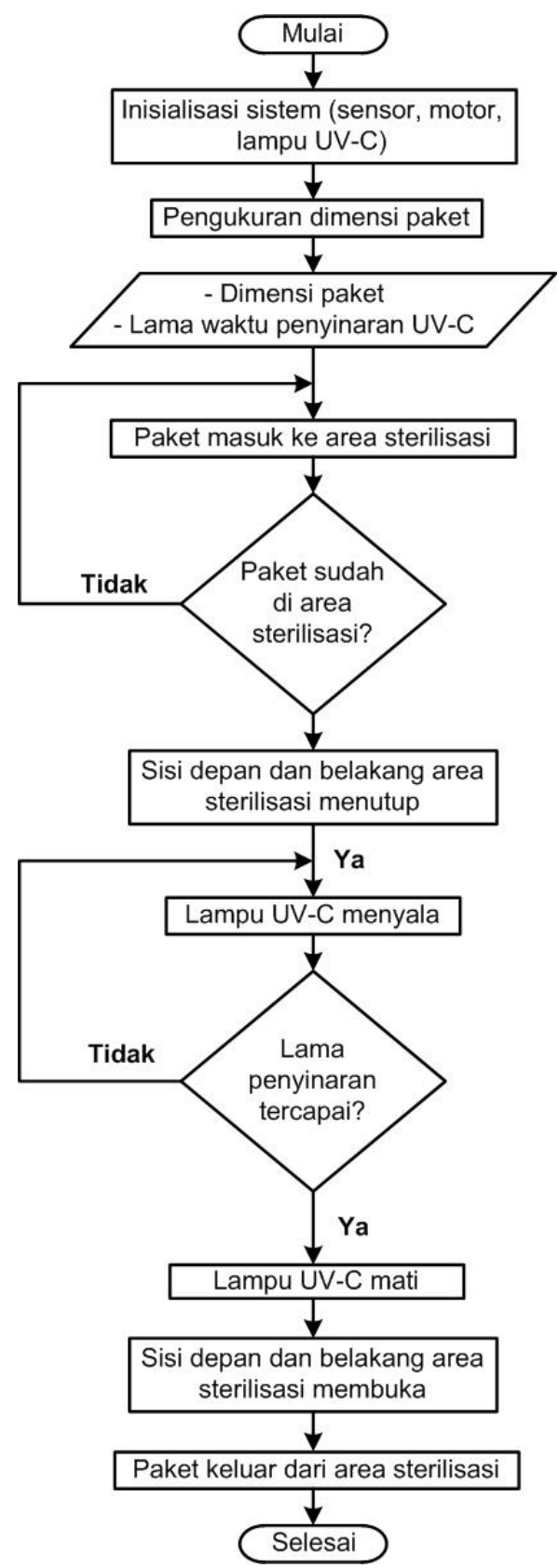

Gbr. 2 Diagram alir kerja sistem.

dilakukan perbaikan yang diperlukan hingga sistem dapat berfungsi sebagaimana yang diharapkan. Selanjutnya dilakukan pengambilan data dan analisis pada sistem yang sudah berfungsi dengan baik, yaitu:

1. penggunaan listrik untuk lampu UV-C;

2. tingkat iradiasi UV-C dengan variasi jarak terhadap area sterilisasi;

3. perhitungan kebutuhan dosis UV-C untuk sterilisasi; dan

4. lama waktu pemaparan UV-C sebagai disinfektan untuk sterilisasi paket.

\section{HASIL DAN PEMBAHASAN}

Hasil rancangan sistem disinfektan UV-C dapat dilihat pada Gbr. 3. Rancangan sistem disinfektan UV-C ini menggunakan 


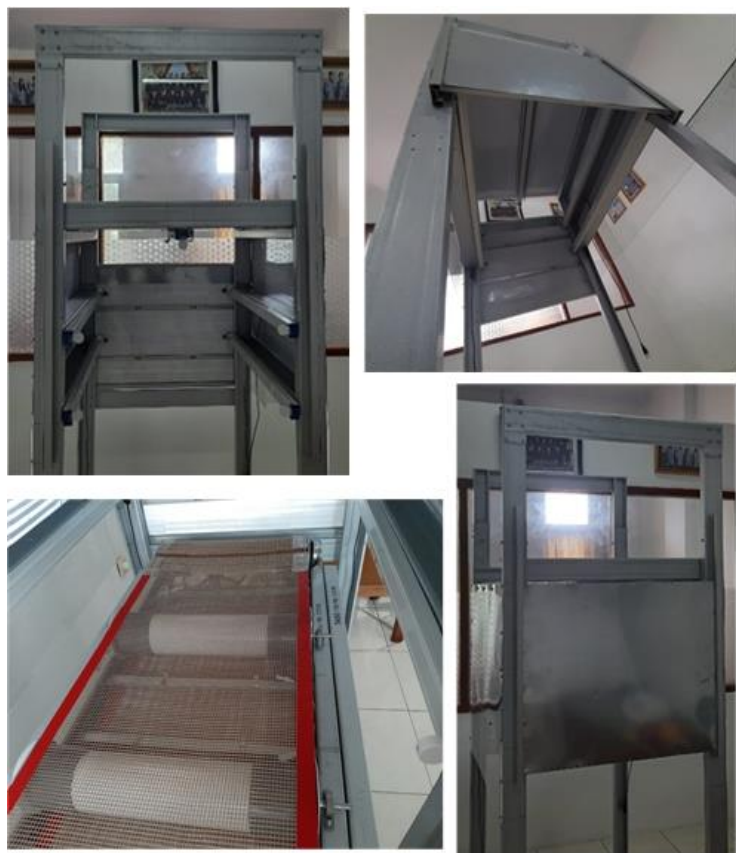

Gbr. 3 Hasil rancangan sistem.

TABEL I

HASIL PENGUKURAN $I_{R}$ UV-C SISI KANAN/KIRI, ATAS, DAN DEPAN/BELAKANG DALAM AREA STERILISASI

\begin{tabular}{|c|c|c|c|}
\hline \multirow{2}{*}{$\begin{array}{c}\text { Jarak } \\
(\mathbf{c m})\end{array}$} & $\begin{array}{c}\text { Kanan/ } \\
\text { Kiri }\end{array}$ & \multicolumn{1}{|c|}{ Atas } & $\begin{array}{c}\text { Depan/ } \\
\text { Belakang }\end{array}$ \\
\cline { 2 - 4 } & $\boldsymbol{I}_{\boldsymbol{R}}\left(\mathbf{m W / \mathbf { c m } ^ { 2 } )}\right.$ & $\boldsymbol{I}_{\boldsymbol{R}}\left(\mathbf{m W} / \mathbf{c m}^{\mathbf{2}}\right)$ & $\boldsymbol{I}_{\boldsymbol{R}}\left(\mathbf{m W} / \mathbf{c m}^{\mathbf{2}}\right)$ \\
\hline 10 & 1,057 & 1,119 & 0,132 \\
\hline 15 & 0,844 & 0,859 & 0,169 \\
\hline 20 & 0,800 & 0,641 & 0,204 \\
\hline 25 & 0,735 & 0,553 & 0,232 \\
\hline 30 & 0,665 & 0,507 & 0,283 \\
\hline 35 & & 0,484 & 0,268 \\
\hline 40 & & 0,470 & 0,284 \\
\hline 45 & & 0,467 & 0,285 \\
\hline 50 & & 0,496 & 0,301 \\
\hline 55 & & & 0,309 \\
\hline 60 & & & 0,311 \\
\hline 65 & & & 0,319 \\
\hline 70 & & & 0,304 \\
\hline
\end{tabular}

lampu UV-C Germicidal Phillips 30 watt sebanyak lima set dan lampu UV-C Germicidal Phillips 8 watt sebanyak delapan set. Pada sisi kanan, kiri, dan atas sistem disinfektan UV-C, lampu dapat dipasang secara memanjang. Pada posisi ini, lampu yang dapat dipasang adalah lampu UV-C 30 watt yang memiliki panjang kap lampu $90 \mathrm{~cm}$. Pada sisi kiri dan kanan masingmasing dipasang dua set lampu UV-C, sedangkan di atas dipasang satu set lampu UV-C. Pada sisi bawah, lampu UV-C 8 watt sebanyak empat set dipasang pada konveyor mini sejajar dengan roller. Lampu UV-C pada sisi depan dan belakang sistem disinfektan dipasang tegak lurus terhadap wire mesh teflon sebanyak masing-masing dua set lampu. Lampu ditempatkan sedemikian rupa agar tidak mengganggu mekanika gerak membuka dan menutupnya sisi depan dan belakang sistem disinfektan UV-C.
TABEL II

PENGUKURAN $I_{R}$ UV-C SISI BAWAH DALAM AREA STERILISASI

\begin{tabular}{|c|r|}
\hline Jarak $(\mathbf{c m})$ & $\boldsymbol{I}_{\boldsymbol{R}}\left(\mathbf{m W} / \mathbf{c m}^{\mathbf{2}}\right)$ \\
\hline 10 & 0,344 \\
\hline 15 & 0,297 \\
\hline 20 & 0,720 \\
\hline 40 & 1,447 \\
\hline 45 & 0,320 \\
\hline 50 & 0,555 \\
\hline
\end{tabular}

TABEL III

HASIl PERHITUNGAN LAMA PAPARAN UV-C Sisi KanAN/KIRI, ATAS, DAN DEPAN/BELAKANG

\begin{tabular}{|c|r|r|r|}
\hline \multirow{2}{*}{$\begin{array}{c}\text { Jarak } \\
(\mathbf{c m})\end{array}$} & $\begin{array}{c}\text { Kanan/ } \\
\text { Kiri }\end{array}$ & \multicolumn{1}{|c|}{ Atas } & $\begin{array}{c}\text { Depan/ } \\
\text { Belakang }\end{array}$ \\
\cline { 2 - 4 } & $\boldsymbol{E}_{\boldsymbol{t} \mathbf{9 0} \text { (detik) }}$ & $\boldsymbol{E}_{\boldsymbol{t} \boldsymbol{9 0} \text { (detik) }}$ & $\boldsymbol{E}_{\boldsymbol{t} \boldsymbol{9 0} \text { (detik) }}$ \\
\hline 10 & 1,99 & 1,88 & 15,91 \\
\hline 15 & 2,49 & 2,44 & 12,43 \\
\hline 20 & 2,63 & 3,28 & 10,29 \\
\hline 25 & 2,86 & 3,80 & 9,05 \\
\hline 30 & 3,16 & 4,14 & 7,42 \\
\hline 35 & & 4,34 & 7,84 \\
\hline 40 & & 4,47 & 7,39 \\
\hline 45 & & 4,50 & 7,37 \\
\hline 50 & & 4,23 & 6,98 \\
\hline 55 & & & 6,80 \\
\hline 60 & & & 6,75 \\
\hline 65 & & & 6,58 \\
\hline 70 & & & 6,91 \\
\hline
\end{tabular}

TABEL IV

Hasil Perhitungan LAMA PAPARAN UV-C SiSi BAWAH

\begin{tabular}{|c|r|}
\hline Jarak (cm) & $\boldsymbol{E}_{\boldsymbol{t} \boldsymbol{9 0}}$ (detik) \\
\hline 10 & 6,10 \\
\hline 15 & 7,07 \\
\hline 20 & 2,92 \\
\hline 40 & 1,45 \\
\hline 45 & 6,56 \\
\hline 50 & 3,78 \\
\hline
\end{tabular}

Dosis UV-C yang diterima setiap perangkat setelah disterilisasi dengan unit pemancar UV-C bervariasi, tergantung pada jarak antara sumber sinar dan area iradiasi [17]. Oleh karena itu, untuk mengoptimalkan iradiasi UV-C pada sistem disinfektan UV-C, semua sisi area sterilisasi dibuat tertutup menggunakan plat seng untuk penempatan stiker reflector warna putih pada sisi dalam area sterilisasi. Terdapat area seluas $90 \mathrm{~cm} \times 22 \mathrm{~cm}$ pada sisi kiri dan kanan bawah area sterilisasi sistem disinfektan UV-C yang tidak ditutup menggunakan plat seng dan stiker reflector. Area ini hanya ditutup menggunakan akrilik bening $2 \mathrm{~mm}$ agar bisa dilakukan pengamatan proses sterilisasi disinfektan UV-C yang terjadi. Area ini tidak mengurangi efektivitas alat karena hanya mengambil area penyinaran UV-C sisi kiri dan kanan bawah dengan panjang $90 \mathrm{~cm}$ dan tinggi $5 \mathrm{~cm}$ serta tidak terdapat radiasi UV-C yang terpancar keluar.

Sistem disinfektan UV-C menggunakan sumber listrik PLN dengan penggunaan listrik rata-rata untuk lampu UV-C pada rancangan ini sebesar 161,77 watt berdasarkan pengukuran menggunakan wattmeter. Hasil pengukuran tingkat iradiasi $\left(I_{R}\right)$ 
TABEL V

LAMA PAPARAN UV-C BERDASARKAN PANJANG PAKET

\begin{tabular}{|c|r|}
\hline $\begin{array}{c}\text { Panjang Paket } \\
(\mathbf{c m})\end{array}$ & $\boldsymbol{E}_{\boldsymbol{t} \mathbf{9 0} \text { (detik) }}$ \\
\hline 70 & 15,91 \\
\hline 65 & 15,91 \\
\hline 60 & 12,43 \\
\hline 55 & 12,43 \\
\hline 50 & 10,29 \\
\hline 45 & 10,29 \\
\hline 40 & 9,05 \\
\hline 35 & 9,05 \\
\hline 30 & 7,42 \\
\hline 25 & 7,42 \\
\hline 20 & 7,84 \\
\hline 15 & 7,84 \\
\hline 10 & 7,39 \\
\hline 5 & 7,39 \\
\hline$<5$ & 7,37 \\
\hline
\end{tabular}

UV-C rata-rata dari tiga kali pengujian dalam area sterilisasi sistem ini, dengan variasi jarak pengukuran terhadap sisi kanan/kiri, atas, depan/belakang area sterilisasi sistem disinfektan UV-C, ditampilkan pada Tabel I. Sementara itu, hasil pengukuran $I_{R}$ UV-C sisi bawah area sterilisasi sistem disinfektan UV-C dengan variasi jarak dari sisi depan area sterilisasi ditampilkan pada Tabel II.

Dosis pemaparan UV-C $(D)$ untuk membunuh $90 \%\left(D_{90}\right)$ virus corona di air adalah sebesar $D_{90}=21 \mathrm{~J} / \mathrm{m}^{2}$ dan di udara adalah sebesar $D_{90}=6 \mathrm{~J} / \mathrm{m}^{2}[16]$. Berdasarkan hasil pengukuran tingkat iradiasi pada Tabel I dan Tabel II, dengan menggunakan $D_{90}=21 \mathrm{~J} / \mathrm{m}^{2}$ dan mengacu pada (1), dapat dihitung $E_{t 90}$, yaitu $E_{t}$ minimal untuk membunuh $90 \%$ virus corona pada sistem disinfektan UV-C.

Untuk jarak benda dari sisi area sterilisasi pada Tabel I, nilai $E_{t 90}$ hasil perhitungan ditunjukkan pada Tabel III. Selanjutnya, untuk jarak benda dari sisi area sterilisasi pada Tabel II, $E_{t 90}$ hasil perhitungan ditunjukkan pada Tabel IV.

Pada Tabel III dan Tabel IV dapat dilihat bahwa $E_{t 90}$ sisi depan/belakang, yaitu selama 6,91-15,91 detik, jauh lebih lama dibandingkan $E_{t 90}$ sisi lainnya. Berdasarkan hal tersebut, diketahui bahwa $E_{t 90}$ setiap paket yang akan disterilisasi dalam sistem disinfektan UV-C yang dirancang bergantung pada panjang paket. Tabel $\mathrm{V}$ memperlihatkan $E_{t 90}$ setiap paket yang akan disterilisasi berdasarkan panjangnya dalam area sterilisasi sistem disinfektan UV-C yang dirancang, dengan paket ditempatkan di tengah area sterilisasi. Dengan pembulatan $E_{t 90}$, lama waktu paparan disinfektan UV-C dapat dibuat dalam dua kategori, yaitu:

1. selama 10 detik untuk paket yang panjanganya sampai dengan $40 \mathrm{~cm}$; dan

2. selama 16 detik untuk paket yang panjangnya $>40 \mathrm{~cm}$ sampai dengan $70 \mathrm{~cm}$.

\section{KESIMPULAN}

Sistem disinfektan UV-C untuk sterilisasi paket melalui konveyor mini yang dirancang membutuhkan daya untuk lampu UV-C sebesar 161,77 watt. Berdasarkan hasil pengukuran iradiasi sistem disinfektan UV-C, diperoleh perhitungan lama paparan UV-C minimal 10 detik untuk panjang paket sampai dengan $40 \mathrm{~cm}$ dan minimal 16 detik untuk panjang paket $>40 \mathrm{~cm}$ sampai dengan $70 \mathrm{~cm}$ agar mampu membunuh virus corona hingga $90 \%$. Semakin lama paparan UV-C, sterilisasi paket oleh sistem disinfektan UV-C ini akan semakin maksimal.

\section{UCAPAN TERIMA KASIH}

Terima kasih disampaikan kepada Lembaga Penelitian dan Pengabdian kepada Masyarakat (LPPM) Universitas Bengkulu yang telah memberikan bantuan dana untuk pelaksanaan penelitian ini.

\section{REFERENSI}

[1] T.P. Velavan dan C.G. Meyer, "Editorial: The COVID-19 Epidemic," Tropical Medicine and International Health, Vol. 25, No. 3, hal. 278-280, Mar. 2020.

[2] A.M. Idhom (2020) "Kronologi Pasien Positif Corona di Indonesia Bertambah Jadi Enam," [Online], https://tirto.id/kronologi-pasien-positifcorona-di-indonesia-bertambah-jadi-enam-eDEn, tanggal akses: 16-Apr2020.

[3] (2020) "90\% Penularan Covid-19 Lewat Cara Ini, Ayo Cegah!," [Online], https://www.cnbcindonesia.com/news/20200405132113-4-149856/90penularan-covid-19-lewat-cara-ini-ayo-cegah, tanggal akses: 16-Apr2020.

[4] K. Barus (2020) "Ikuti Himbauan Pemerintah, Sicepat Lakukan Langkah Pencegahan Terkait Wabah Virus Corona," [Online], https://www.industry.co.id/read/62575/ikuti-himbauan-pemerintahsicepat-lakukan-langkah-pencegahan-terkait-wabah-virus-corona, tanggal akses: 16-Apr-2020.

[5] A. Puspitoningrum (2020) “Cegah Penularan Covid-19 Lewat Barang, Ini yang Dilakukan JNE," [Online], https://jateng.idntimes.com/ business/economy/anggun-puspitoningrum-1/cegah-penularan-covid-19lewat-barang-ini-yang-dilakukan-jne, tanggal akses: 16-Apr-2020

[6] E. Waltz (2018) "UV Gadgets and Virtual Docs Take On a Very Bad Flu Season," [Online], https://spectrum.ieee.org/the-human-os/ biomedical/ devices/high-tech-flu-fighters, tanggal akses: 24-Jun-2020.

[7] A.P. Kasih. (2020) "Gunakan Sinar UV, Bilik Disinfeksi Karya FT-UI Matikan Virus 10 Detik" [Online] https://www.kompas.com/edu/read/2020/03/27/091913871/gunakansinar-uv-bilik-disinfeksi-karya-ft-ui-matikan-virus-10-detik. tanggal akses: 28-Apr-2020.

[8] T.P. Sun, C.T. Huang, P.W. Lui, Y.T. Chen, dan H.L. Shieh, "Novel Measurement System for Linear Array Type UVC Germicidal System," 2019 IEEE Eurasia Conference on Biomedical Engineering, Healthcare and Sustainability (IEEE ECBIOS 2019), 2019, hal. 57-60.

[9] A.D. Elisanti, E.T. Ardianto, N.C. Ida, dan E. Hendriatno, "Efektifitas Paparan Sinar UV dan Alkohol 70\% Terhadap Total Bakteri pada Uang Kertas yang Beredar Dimasa Pandemi Covid-19," Jurnal Riset Kefarmasian Indonesia, Vol. 2, No. 2, hal. 113-121, Mei 2020.

[10] F.Z. Ramdhani, D. Riyanto, dan Desriyanti, "Electronic Sterilization of Tableware Using Ultraviolet Light Radiation," Journal of Electrical and Electronic Engineering-UMSIDA, Vol. 4, No. 1, hal. 70-79, Apr. 2020.

[11] F. Siswanto dan S.H. Suryo, "Rancang Bangun Alat Germicidal Udara Menggunakan Sinar Ultraviolet," Jurnal Teknik Mesin S-1, Vol. 3, No. 3, hal. 264-273, Jul. 2015.

[12] M. Bentancor dan S. Vidal, "Programmable and Low-cost Ultraviolet Room Disinfection Device," HardwareX, Vol. 8, Article e00046, hal. 113, Okt. 2018.

[13] Yuliana, "Corona Virus Diseases (Covid-19); Sebuah Tinjauan Literatur," Wellness and Healthy Magazine, Vol. 2, No. 1, hal. 187-192, Feb. 2020.

[14] Z. Wang, W. Qiang, dan H. Ke, A Handbook of 2019-nCoV Pneumonia Control and Prevention, Hubei, China: Hubei Science and Technologi Press, 2020. 
[15] D. Cycleback, Ultraviolet Light and Its Uses, $1^{\text {st }}$ ed., Bookboon The eBook Company, 2018, tanggal akses: 30-Okt.-2020, [Online], https://bookboon.com/en/ultraviolet-light-and-its-uses-ebook.

[16] W. Kowalski, Ultraviolet Germicidal Irradiation Handbook UVGI for Air and Surface Disinfection, Berlin Heidelberg, Germany: SpringerVerlag, 2009.
[17] M. Linblad, E. Tano, C. Lindahl, dan F. Huss, "Ultraviolet-C Decontamination of a Hospital Room: Amount of UV Light Needed," Burns, Vol. 46, No. 4, hal. 842-849, Jun. 2020. 